\title{
Rare and interesting moss records from Egypt
}

\section{Hanaa Mostafa Shabbara}

Faculty of Science, Ain Shams University, Cairo, Egypt

E-mail: wagelsaadawi@yahoo.com

Shabbara H.M. 2006. Rare and interesting moss records from Egypt, Cairo Egypt. Taeckholmia 26: 121-129.

\begin{abstract}
Four new rare moss taxa are recorded from Egypt; Archidium alternifolium (Dicks. ex Hedw.) Mitt., Barbula arcuata Griff., Leptobarbula berica (De Not.) Schimp. and Plaubelia sprengelii (Magill) H. Zander. Archidium, Leptobarbula and Plaubelia represent new genera to Egypt. Barbula arcuata is a new record to Africa. Plaubelia sprengelii is disjunct taxon to America.
\end{abstract}

Key words: mosses, rare, Archidium, Leptobarbula, Plaubelia, Barbula arcuata, Egypt.

\section{Introduction}

The term 'rarity' invokes many different definitions and responses in modern scientific and management circles. To some 'rare species' are those that show global decline. Others consider 'rare species' as those that occur at low abundance within a local area, even though they may have wide geographic ranges" (Heinlen \& Vitt, 2003). In Egypt, according to our present knowledge, many taxa of mosses seem to be rare; they occur at very low abundance in one or a few sites. Without a published checklist including rare mosses it is difficult to report new species to an area as well as to assess which species may be considered rare at the country level. One of the main difficulties in making such a checklist is identifying species (Hedderson, 1992). In Egypt most of rare mosses are young or small enough to be confused in identification with other taxa (personal observation). This

Received 15 October 2006, Revision accepted 12 December 2006 
may be attributed to the decline of these taxa in the national flora (as a result of disturbance or pollution) or being introduced or migrating from other regions (long range dispersal) but not well established yet in Egypt. Thus, many such taxa have been neglected from the list of mosses (179 taxa) representing moss flora of Egypt (see Shabbara \& El-Saadawi in 2006) being unidentified or identified to only the generic level or sometimes even misidentified. So, the aim of this paper is to correct and report in some detail on four of such neglected rare taxa namely; Archidium alternifolium (Dicks. ex Hedw.) Mitt., Barbula arcuata Griff., Leptobarbula berica (De Not.) Schimp. and Plaubelia sprengelii (Magill) H. Zander. These taxa are new to Egypt representing three new genera; Archidium, Leptobarbula and Plaubelia and one new family; Archidiaceae, while Barbula arcuata and Plaubelia sprengelii are furthermore new to Africa at large. Reference is made to the distinguishing characters of these four taxa compared to those recorded in other regions of the world. Natural photographs are provided for $B$. arcuata and $P$. sprengelii (being new to Africa) while only line drawings are provided for the two other mosses. Sporophytes and gametangia are absent in three of them; Archidium alternifolium, Barbula arcuata and Leptobarbula berica, however this is a common phenomenon in disturbed habitats (cf. During, 1979). This study will be followed by other ones to assess these four taxa and report in some detail on other previously neglected ones.

\section{Identification}

1- Archidium alternifolium (Dicks. ex Hedw.) Mitt. Ann. Mag. Nat. Hist., 1851.

(Fig. 1 a-d)

As the unique diagnostic characters of Archidium are the deeply immersed capsule and its few (up to 15) and large (up to $310 \mu \mathrm{m}$ ) spores, the absence of sporophytes (as in the present sample) makes confusion with Bryum (as in Shabbara, 1990) very likely. Both of them possess prosenchymatous cells and heteromorphic leaves.

Careful examination, however, showed that the present specimen belongs to Archidium alternifolium which is characterized by long narrow subulate comal leaves, differentiated alar cells and a terete stem with a central cylinder consisting of large, rather thin-walled cells. Measurements of the present specimen lie in the normal range 
and not in the extremes of its known wide range (Snider, 1975). But the plant recorded here from Egypt seems to be young with no innovations, no gametangia, no sporophytes and even no gemmae. Having finely serrulate and plane margins distinguish this taxon from A. tenerrimum Mitt. which is recorded in North America (Snider, 1994). A. alternifolium is already known from North Africa, however, it is described by Snider (1975) as being rare in that region.

Specimen examined: Nile Delta, Rosetta, cultivated area small patch, on cement of a red-brick wall of a basin, October 1987. HS2053.

World distribution: Europe; southern temperate regions, Iceland, North Asia, South-west Asia; Turkey; North Africa; Algeria, Canary Islands, Morocco and Tunisia; North America \& Central America; Mexico, Arizona,

Diagrams \& descriptions: Snider (1975, p.129-132, Plates VII and VIII).

2- Barbula arcuata Griff., Calcutta J. Nat. Hist. 2: 491. 1842.

(Fig. 2 a-e)

This taxon is characterized by leaves being triangular, gradually narrowed from \pm cordate base, possessing smooth or crenulate laminal cells. The presence of two well developed stereid bands and exterior costal epidermal cells differentiate this taxon from other related Didymodon and Barbula species recorded in Egypt. The sinuose costa and denticulate extreme tip of leaf recorded in Mexico (Zander, 1994) is also found in the Egyptian specimen.

Although there is great similarity in both morphological and anatomical characters of the investigated Egyptian plant and B. arcuata (particularly that recorded from Mexico), the dimensions of the Egyptian plant show some differences. While width of its upper laminal cells lies in the lower extreme $(6 \mu \mathrm{m})$ of those recorded in either Asia or America (Saito, 1975 \& Zander, 1994 respectively) the length of the Egyptian plant is far below limit (2mm high). It is up to $10 \mathrm{~mm}$ high in Japan (Saito, 1975) and to 25 $\mathrm{mm}$ in Mexico (Zander, 1994). ). Also, gemmae are not detected in the Egyptian plant. Chen (1941) distinguished Hydrogonium soboliferum (= Barbula sobolifera) from $H$. comosum (= B. arcuata) only by the occurrence 
of gemmae in the latter. But, as other morphological characters of Barbula sobolifera agree with those of Barbula arcuata, Saito (1975) put it as synonym to $B$. arcuata.

The small dimensions of $B$. arcuata of Egypt in addition to lack of axillary hairs, gemmae, gametangia and sporophytes may be due to young age of the collected specimen. This record of Barbula arcuata is new to North Africa

Specimen examined: Faiyum, on the way from Faiyum city to AlAgamean, Ezbet Abou-Shanab, small patch in cultivated area, on a lime stone continually splashed with water, 27/2/1984. HS0015f

World distribution: Southern Asia; Japan, Malaise, New Guinea, Philippine and western Oceania, Central America; Cuba, Guatemala and Mexico, Southern America; Brazil and Venezuela.

Diagrams \& descriptions: Saito (1975, p. 496, Fig. 47; 19-32); Zander (1994, p. 292-295, Fig. 218).

\section{3- Leptobarbula berica (De Not.) Schimp.}

(Fig.1 f-i)

Leptobarbula berica having ligulate leaves with obtuse apecies make it closely related to Semibarbula. This led to misidentification by Lashin (1990). However, many characters of this latter genus (as recorded by Chopra, 1975) are absent in samples studied by Lashin (1990). These characters are; the distinctly large plant size, the recurved margin of the leaves, and the strong nerve. In addition, Semibarbula is put by Zander 1993 under genus Barbula which is different from the present taxon.

The studied specimen may be confused with Gyroweisia tenuis (Schrad. ex Hedw.) Schimp., however the latter has wider leaves with wider base and longer basal cells. But characters of the present specimen are those of Leptobarbula berica. Its diagnostic characters (according to Zander, 1993) are: the small size of plant, ligulate leaves with plane margin, small quadrate upper cells, slightly differentiated base and two costal bands. But the dorsal stereid band characteristic of $L$. berica is very weak or mostly absent in Egypt, and likewise in both Spain (Guerra, 2004) and England (Appleyard et al. 1985).

Matching characters of the studied specimen with those recorded in Spain (Guerra, 2004) and England (Appleyard et al. 1985), one can notice that this specimen is rather closer to the Spanish specimen than to the British one. It is $c a .4 .5 \mathrm{~mm}$ high in Egypt, 2.5 (7) $\mathrm{mm}$ in Spain while up to 
only $2 \mathrm{~mm}$ in Britain. The leaf cell width is $4-8 \mu \mathrm{m}$ for upper cells and 8$11 \mu \mathrm{m}$ wide for basal cells in both Egypt and Spain while it is 3-6 $\mu \mathrm{m}$ for

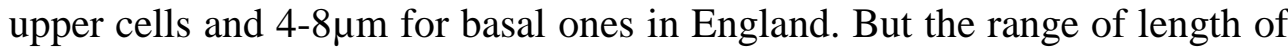
basal leaf cells recorded in Spain is limited towards the high extreme (20$22 \mu \mathrm{m})$ compared to that in Egypt $(8-22 \mu \mathrm{m})$. The fusiform apical gemmae of Leptobarbula berica are also recorded in both Egypt and Spain but absent in England. The specimen in Egypt has no gametangia and no sporophytes but gametangia are recorded in both Spain and England while sporophytes are recorded only in Spain. Thus, in the absence of the characteristic perichaetial leaves the identification of the Egyptian specimen as Leptobarbula berica remains provisional.

Specimen examined: Suez Canal zone, Tossum, Al-Doba'iyah village, a small patch on very moist mud covering a semishaded red-brick wall, 15/ 10/ 1987, G 298.

World distribution: Of local occurrence in the Mediterranean region of Europe, England, North Africa; Morocco, Tunisia and South-West Asia; Lebanon, Israel and Turkey, South-East Asia.

Diagrams \& descriptions: Zander (1993, p.203, Figs 78; 2-4).

4- Plaubelia sprengelii (Magill) H. Zander. Syn. Neohyophila sprengelii (Schwaegr.) Crum

(Fig.2 f-h)

The studied specimen has some distinctive characters; spathulate rosulate leaves, incurved margins, ventrally bulging laminal cells and costal epidermal cells and the presence of two stereid bands and well developed peristome teeth. The first four characters indicate that the taxon may belong to genus Hyophila. But having well developed peristome teeth rejects it from consideration. The unique combination of the above mentioned six characters is found (according to Zander, 1993) in Plaubelia sprengelii (Magill) $\mathrm{H}$. Zander. Matching characters of the studied specimen with those recorded in America (Zander, 1983) for P. sprengelii shows that measurements of the present specimen lie in the normal range. But the specimen collected from Egypt may represent a different form from that of both Bartlett 12541 (FH) from Guatemala and Proctor 15463 (MICH) from Haiti (Zander, 1983). It compares well with the former specimen in leaf length, leaf widest part, leaf apex and 
presence of two stereid bands while it differs from the latter specimen regarding these characters. But the costa of the studied specimen is different from that of both Haiti and Guatemala specimens. It ends below apex by 2 cells in the Egyptian sample while it is percurrent and very shortly excurrent in Haiti and Guatemala respectively, (Zander, 1983). Also, spore diameter is 8$10 \mu \mathrm{m}$ in America while $15-17 \mu \mathrm{m}$ in Egypt. However, according to Zander (1983) many specimens, including type specimen, have intermediate characters of the two varieties of Plaubelia sprengelii (var. sprengelii and var. stomatodonta).

Specimen examined: Isthmic Desert, Gebel Maghara, on fine sediments between rocks in runnels on north-facing slopes, $215 \mathrm{~m}$, a few individuals, sporophytes recorded in two individuals, 17/4/1995, WEm310-8.

World distribution: North, Central \& South America (except southern parts). Diagrams \& descriptions: Zander (1983, p.136, Figs 7-10).

Disjunct between Northern Sinai and America. This type of disjunction is common among xerophytic mosses of arid and semiarid zones (steppe climates) of the Northern Hemisphere (Schofield, 1988; Shabbara, 1999).

\section{Acknowledgement}

Sincere thanks are due to Prof. Dr. W.El-Saadawi, Botany Department, Faculty of Science, Ain Shams University for his illuminating criticism.

\section{References}

Appleyard, J., Hill, M.O. and Whitehouse, H.L.K. 1985. Leptobarbula berica (De Not.) Schimp. in Britain. Journal of Bryology 13: 461-470.

Chen, P.C. 1941. Studien über die ostasiatischen Arten der Pottiaceae. I \& II. Hedwigia 80:1-76.

Chopra, R.C. 1975. Taxonomy of Indian Mosses (An Introduction). New Delhi: Publications \& Information Directorate (CSIR).

During, H. J. 1979. Life strategies of Bryophytes: a preliminary review. Lindbergia 5(1): 2-19.

Guerra, J. 2004. Leptobarbula Schimp. In Guerra J., Cros RM., eds. Flora Briofitica ibérica Murcia: Socieded Español de Briologia 20-22.

Hedderson, T.A. 1992. Rarity at range limits: dispersal capacity and habitat relationships of extraneous moss species in a boreal Canadian National Park. Biological Conservation 59: 113-120. 
Heinlen, E.R. and Vitt, D.H. 2003. Patterns of Rarity in Mosses of the Okanogan Highlands of Washington State: An Emerging Coarse Filter Approach to Rare Moss Conservation. The Bryologist 106 (1): 34-52.

Lashin, G. 1990. Studies on the Bryoflora of Suez Canal Region. M.Sc. Thesis. Botany Department. Faculty of Science. Zagazig University. Zagazig.

Saito, K. 1975. A monograph of Japanese Pottiaceae (Musci). The Journal of the Hattori botanical Laboratory 39: 373-537.

Schofield, W.B. 1988. Bryophyte disjunctions in the Northern Hemisphere: Europe and North America. Botanical Journal of the Linnean Society. 98: 211-224.

Shabbara, H.M. 1990. Studies on the bryoflora of the Mediterranean Coast of Egypt. Ph.D. Thesis. Botany Department, Faculty of Science, Ain Shams University.Cairo.

1999. Three new records of Funariaceae from Egypt. Journal of Bryology 21: 201- 205.

and El-Saadawi, E. 2006. Mosses from Gebel Maghara with new records for Isthmic Desert and Egypt. Cryptogamie bryologie 27 (2): 285-295.

Snider, J.A. 1975. A revision of the genus Archidium (Musci). The Journal of the Hattori botanical Laboratory 39: 105-201.

1994. Archidium Brid. In Sharp AJ., Crum H., Eckel PM., eds. The Moss flora of Mexico. New York: the New York Botanical Garden, 24-28.

Zander, R.H. 1988. A Reevaluation of Neohyophila Crum (Pottiaceae). The Bryologist 86(2): 134-139.

1994. Barbula in Sharp, Crum and Eckel, eds. The Moss flora of Mexico. The New York Botanical Garden. P. 286-299. 


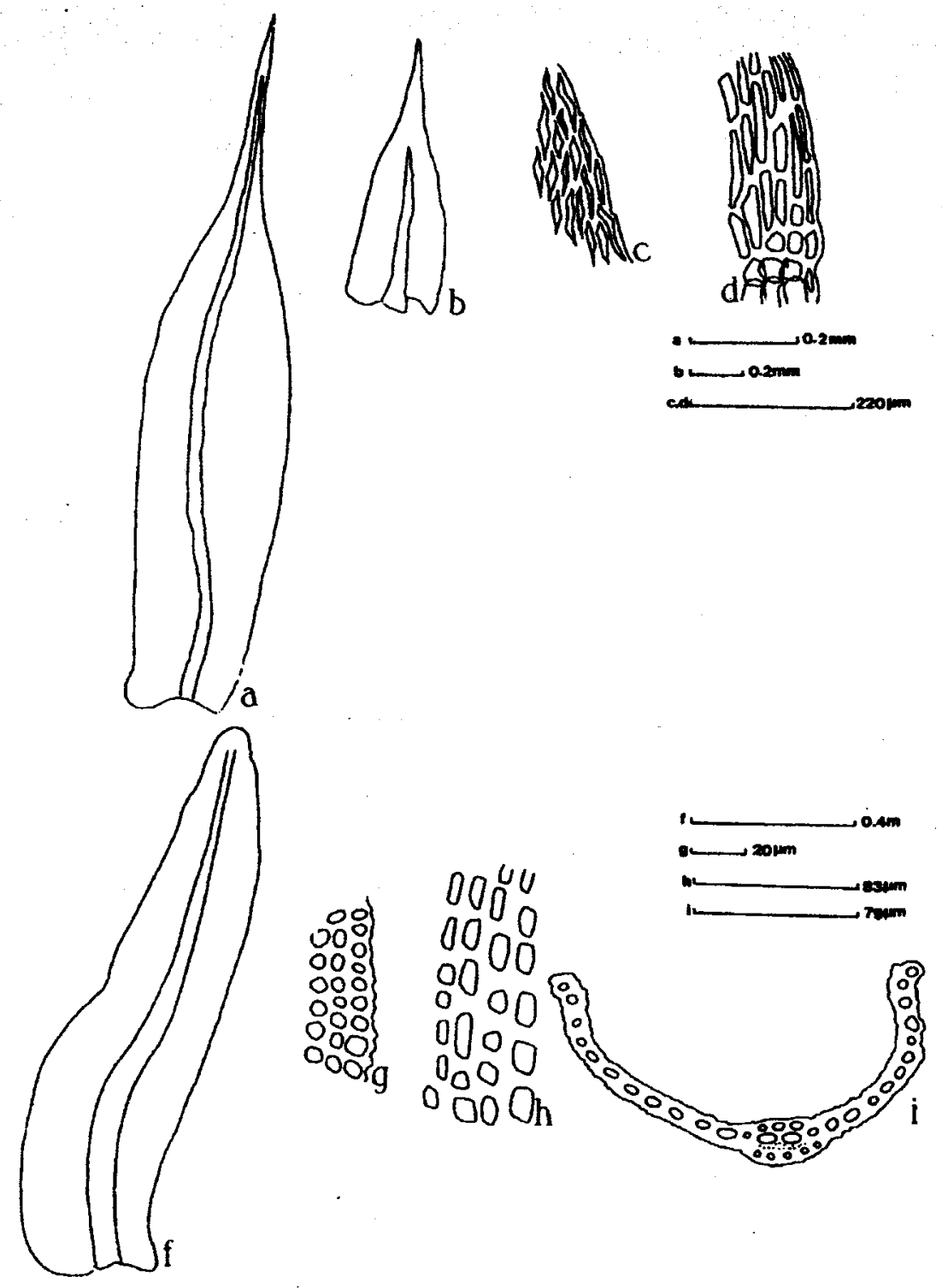

Figure 1. (a-d) Archidium aliernifolium (Dicks. ex Hedw.) Mitt: a, uppei stem leaf, bacal stam leaf; c, upper lamianl cells; d, beeal haminal cells.(f-i) Leprobarbula berica (De Not.) Schimp.: f.

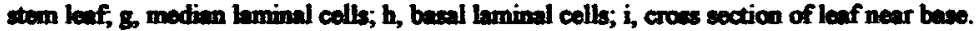



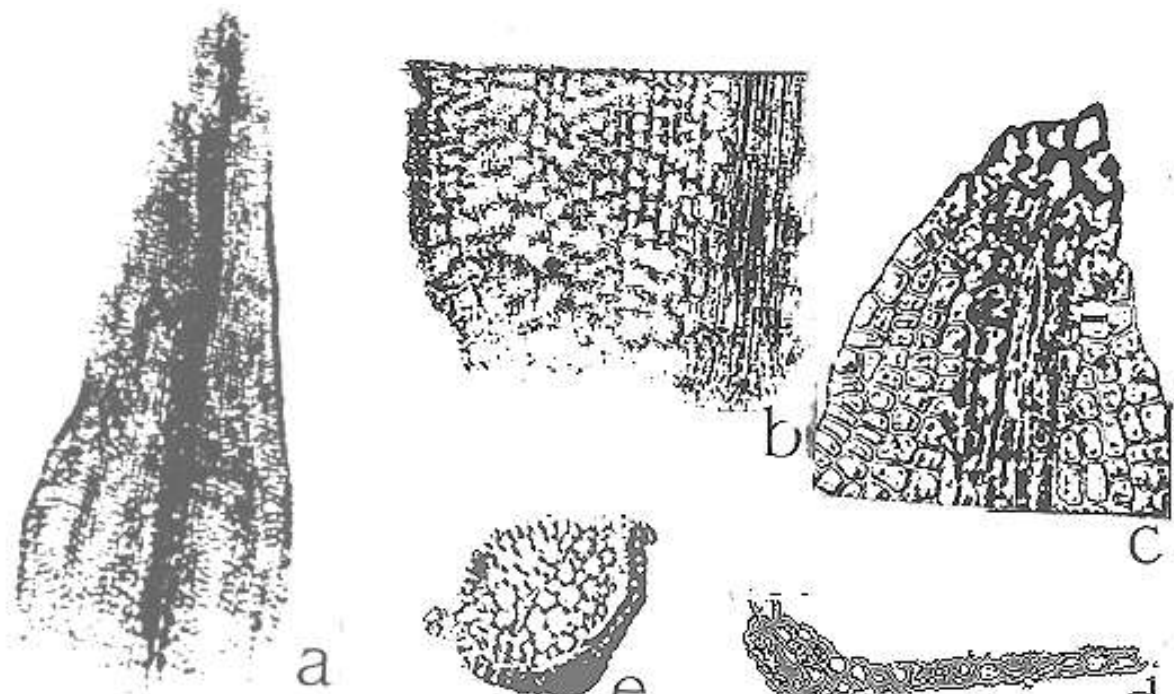

a
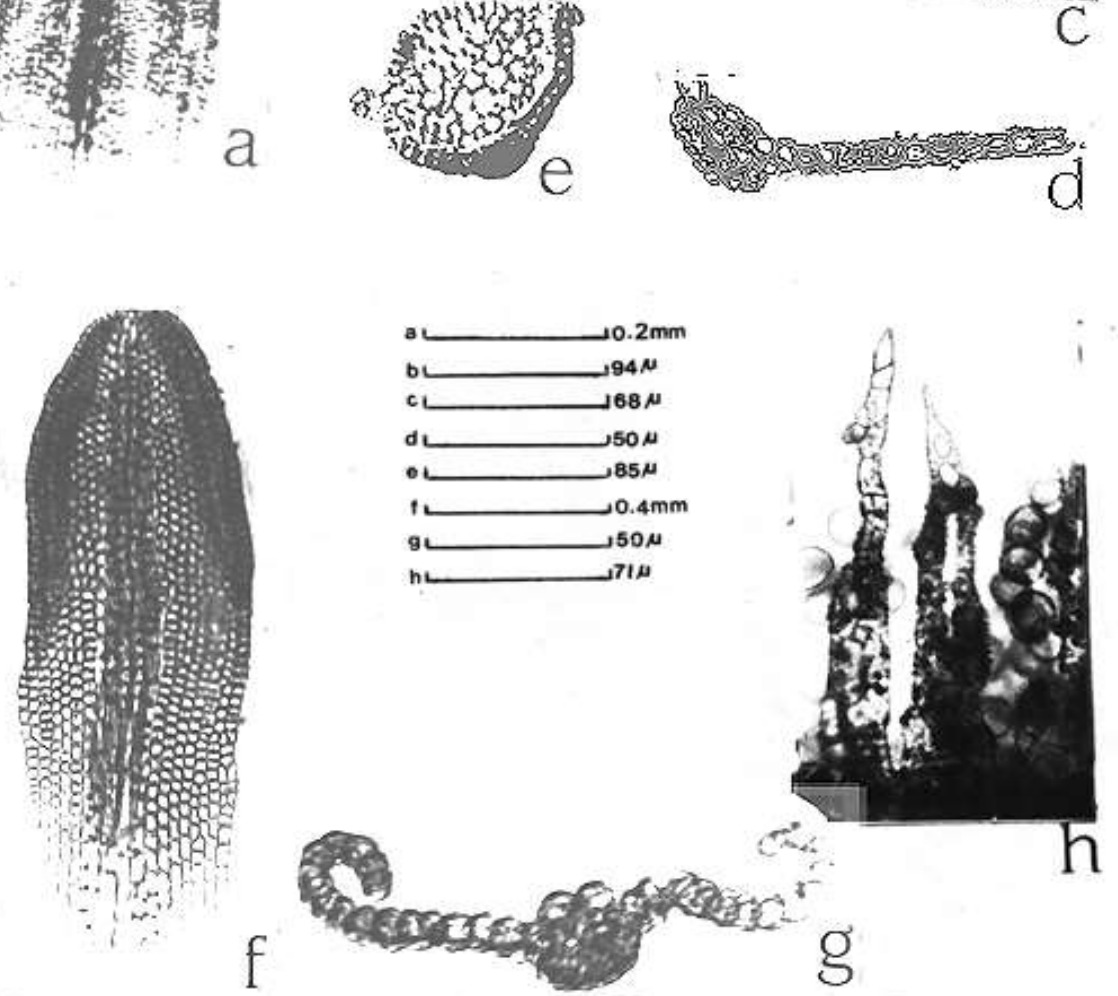

Figure 2. (a-e) Barbula arcuata Griff.: a, stem leaf, b, part of stem leaf base; c, stem leaf apex; d, part of cross section of upper stem leaf, e, cross sections of leaf and stem in lower parts. (f-h) Plaubelia sprengelit (Magili) H. Zander: f- stem leaf, g, cross section of leaf in the upper portion; h, peristome teeth. 